\title{
DEVELOPMENT OF ATHLETIC INSTRUCTIONAL LEARNING MEDIA BASED ON ANDROID STUDIO AND ADOBE ANIMETE APPLICATIONS IN 2020
}

\author{
*Rizky Hasan Azhari Ritonga, Imran Akhmad, M. Irfan \\ Correspondence: State University of Medan, Medan, Indonesia \\ E-mail: Rizkyhasan676@gmail.com
}

\begin{abstract}
This research is motivated by the lack of interesting learning media innovations that exist for learning PJOK, especially athletics and the difficulty of some students in understanding the basic athletic movements taught in schools because of the lack of student interest in learning PJOK, especially athletics when in class or learning theory. This study aims to develop an Athletic Smart Apps application with athletic materials, especially the shooting and javelin throwing branches based on Android Studio and Adobe Animate for VII grade junior high school students. This research is a about development research or Research and Development which uses the Borg and Gall development model. The research and development stages consist of: (1) Research on existing products, (2) literature studies and field studies, (3) planning to make product designs. (4) Internal testing of designs, (5) Revising designs, (6) Making products, (7) Conducting limited trials, (8) Conducting product revisions 1, (9) Conducting main field trials, (10) Conducting product revision 2. Validation is carried out by material experts and media experts. The media developed was tested on 35 students of class VII-A SMP N3 Huraba Mandailing Natal. The results of this research were obtained: 1. The creation of an application product for the development of an athletic instructional instructional media application based on Android Studio and Adobe Animate for grade VII students of SMP N3; 2. Feasibility has been well tested in terms of material, media and usability factors with the category "Very Appropriate" at each testing stage. The results of the expert validation test: 1. The material expert validation value is 4.25 , which is in the range $>4.0$ so that it is included in the "Very Appropriate" category; 2. The validation value of Media Experts is 4.70 in the range> 4.0 so it is included in the "Very Appropriate" category. The usability factor feasibility test results of 6.24 are in the range> 5.5 so that it is included in the "Very Feasible" category. Thus, athletic learning media with android studio and adobe animate-based applications are suitable for use as learning media for PJOK athletic sports, especially for grade VII junior high school students.
\end{abstract}

Keywords: Athletics based on android studio and adobe animate, learning media, Research and Development using the Borg and Gall development model.

PJKR

https://jurnal.unimed.ac.id/2012/index.php/jpehr 


\section{Introduction}

Information and communication technology (ICT) has developed so rapidly, this development has an inevitable impact. This impact requires innovation and creativity in various ways, one of which is in the world of education. Therefore it is not difficult anymore to find the use of ICT in the world of education. One example is that almost all Indonesians already have smartphones and Androids. The success of Android is inseparable from its open source nature, which is to provide free software source code so that 7 developers can develop, distribute and duplicate it without the need to pay for any license. In addition, Android has provided free and paid applications by Android developers to make it easier for users. Currently, many applications are provided through the Play Store and users only need to download and install them on a smartphone. But until now there are still few athletic learning media applications available on the Play Store, especially in the Indonesian language format. Therefore, through this final project, the writer is motivated to develop learning media based on Android studio and adobe animate in the form of an affection for the subject of PJOK in Athletic Material for class VII, especially the number of shooting and throwing javelins, according to the basic competencies taught in the class .

Learning through smartphone media will be more practically done anywhere and anytime so that it can make it easier for students to learn. And knowing the background of students (psychological, physical and environmental) which is useful for both placement and determining the causes of student learning difficulties, which serves as input for the task of Guidance and Counseling (BP). The final goal of developing learning is as feedback for teachers which in turn can be used to improve the teaching and learning process and remedial programs for students.

Implementation of learning effectiveness needs to develop learning, development is important in teaching and learning activities. Therefore, in carrying out development, especially physical education subjects, it should be carried out carefully and carefully and refers to the principles of good evaluation, all of which is done in order to obtain information about student learning outcomes as a whole regarding cognitive, affective, and psychomotor aspects.

The results of observations made by the author in several schools in Mandailing Natal, especially in Siabu District, obtained information that there were difficulties for PJOK teachers in teaching online, for example finding and making learning for students who were truly relevant to the material and also the teacher had difficulty when demonstrating several movements due to online teaching and learning, this situation causes many students to have difficulty understanding the movements taught by PJOK teachers, while students are required to be able to master learning while there are still Physical Education teachers who have not included cognitive aspects in their development process, especially at this time using the DARING system (online) is still far from the maximum. The teacher still thinks that what can be done at this time is only using

PJKR

https://jurnal.unimed.ac.id/2012/index.php/jpehr 
online meetings so that there are no affective and psychomotor aspects, while the cognitive development we get can only be done in learning theory in class.

In addition, the teacher evaluation process is not objective yet, this is indicated by the existence of the term " controlling value '/ human value in making assessments. This of course shows that the effectiveness or learning development process has not been carried out optimally because it does not show the real ability of students and the evaluation process has not been carried out as a whole. The information obtained from teachers and students shows the importance of developing instructional media that can overcome the problems of learning in teaching and learning. The development of learning media is expected to support the achievement of learning objectives at the school.

Journal of the National and Kapodestrian University of Athens, Faculty of Physical Education and Sport Science, Athens, Greece (2011), a study on the effectiveness of using technology in the teaching of motor skills has recently attracted the interest of researchers for the bulk of the increase in the number of scientific journals published in its entirety. unit or even a problem regarding this topic. In addition, many researchers are experimenting with the development and application of visual teaching tools, digital multimedia and virtual learning environments for teaching motor skills. In order to improve the quality of physical education learning for sports and health, the author created an Androidbased application.

\section{Conclusion}

From the results of the school's need much the materials that must be mastered by students, with this Android-based application students can more easily access subjects and materials, so that teaching and learning activities are effective, intractive and fun, so than they can have an influence in increasing children's cognitive abilities.

In line with the research results, the existence of Android-based applications has an effect on cognitive abilities, it is necessary to conduct a study of the learning process in units of SMP / MTS education levels. An increasingly modern situation has led teenage children to grow towards technological advances that have entered the digital era. Android-based Athletic Smart Apps need to be further developed in terms of smartphones. This application can be developed to be installed on all operating systems other than Android, namely the Iphone Operating system, Windows Phone, and Blackberry

\section{References}

Arsyad, Azhar. (2011). Media Pembelajaran. Jakarta: Rajawali

Anfasa, Farid. 2010. Paradigma Pendidikan Nasional Abad XII. BSNP. Vol.1, November 2010. Diambil dari http://www.dikti.go.id/dmdocuments/BSNPParadigmaAbad21- 
Adang, Suherman. (2000). Dasar-dasar Penjaskes. Jakarta : Departemen Pendidikan Nasional Direktorat Jenderal Pendidikan Dasar Menengah Bagian Proyek Penataran Guru SLTP Setara D-III.

Dimyati dan Mudjiono. (2009). Belajar dan Pembelajaran. Jakarta: PT. Rineka Cipta Depdiknas. (2003). Kurikulum 2004 Standart Kompetensi Sekolah Pertama.Jakarta: Depdiknas

Dwi, Gian. (2015). "Pengembangan Media Pembelajaran Berbasis Android Dalam Bentuk Buku Saku Digital Untuk Mata Pelajaran Akutansi Kelas XI". Skripsi. FE UNY

Eddy Purnomo. ( 20011), Dasar-dasar Gerakan Atletik. Yogyakarta: Alfamedia

EMarketer. (2015). 2015, Pengguna Smartphone di Indonesia Capai 55 Juta. Yang diakses melalui:

http://techno.okezone.com/read/2015/09/19/57/1217340/2015-

penggunasmartphone-di-indonesia-capai-55-juta

Gegne, R, M, Briggs, L.J.\& Wagner,W,W.1992. Principles of instructional Desain (4t ed). New York; Holt, Reinhart and Wiston

IAAF. (2009). Run! Jump! Throw!. Monaco:

IDC (International Data Corporation). (2014). Smartphone OS Market Share, Q3 2014 yang diakses melalui http://www.idc.com/prodserv/smartphoneosmarket-share.jsp

Jatmika, Maya. (2005). "Pemanfaatan Media Visual dalam Menunjang Pembelajaran Pendidikan Jasmani di Sekolah Dasar”. Jurnal Pendidikan JasmaniIndonesia. Vol.3, No.1

http://journal.uny.ac.id/index.php/jpji/artcle/view/6176/536

Masfufah, Dwi. (2015). "Pengembangan Media Pembelajaran Mobile Learning Berbasis Android Materi Virus Untuk Siswa Kelas X SMA/MA”. Skripsi. FMIPA UNY

Nugraha, Fakhri. 2014. Siswa_Dalam Pembelajaran Aktivitas Atletik Nomor Lari Jarak Pendek. Pendidikan Indonesia. Repository.upi.edu. Diambil dari: http://repository.upi.edu/15968/4/S_PJKR_0900342_Chapter1.pdf

Panji Wisnu Wirawan. (2011). Pengembangan Kemampuan E-Learning Berbasis Web ke dalam M-Learning. Jurnal Universitas Diponegoro. (Vol. 2. No. 4 $101 \mathrm{Hlm}$ 22-23).

http://ejournal.undip.ac.id/index.php/jmasif/article/view/2655

Purnomo. Eddy. (2007). Pedoman Mengajar Dasar Gerak Atletik. Yogyakarta: Universitas Negeri Yogyakarta Purbasari,

Rohmi Julia. (2013). "Pengembangan Aplikasi Android Sebagai Media Pembelajaran Matematika Pada Materi Dimensi Tiga Untuk Siswa SMA Kelas X”. Skripsi. FMIPA UNY

Rachman, Hari Amirullah. (2014). "Pengembangan Multimedia Pendidikan Jasmani Budaya Hidup Sehat untuk Sekolah Menengah Atas". Jurnal $\begin{array}{llll}\text { Pendidikan Jasmani } & \text { Indonesia. } & \text { Vol.2, } & \text { No.1 }\end{array}$ http://journal.uny.ac.id/index.php/jolahraga/article/view/2565/2119

PJKR_

https://jurnal.unimed.ac.id/2012/index.php/jpehr 
Rosdiana, Dini. (2013). Perencanaan Pembelajaran Dalam Pendidikan Jasmani

Dan Kesehatan. Bandung: Alfabeta

Sagala ( 2008 ), Konsep dan Makna Pembelajaran, Alfabeta Bandung.

Sugiyono. (2011). Metode Penelitian Kuantitatif Kualitatif dan R\&d. Bandung: Alfabeta

Sugiyono. (2015). Metode Penelitian dan Pengembangan Research and Development. Bandung: Alfabeta

Sumber Belajar Kemdikbud. (2013). Jenis dan Klasifikasi Media Pembelajaran. Yang diakses melalui

https://sumberbelajar.belajar.kemdikbud.go.id/PTP/Konten\%20Materi/91\%

20Anas\%20Sabayasa/diklat\%20113/modul\%20218/Buku/Materi\%202_Me dia\%2

Tri, Edy Baskoro. 2012. Paradigma Pendidikan Nasional Abad XXI. Litbang Kemendikbud. Litbang Kemdikbud. Vol.6, Desember 2012.Diambil dari : http://litbang.kemdikbud.go.id/data/bsnp/buletin/Buletin-Edisi-4-2011.pdf Yuntoto, Singgih. (2015). "Pengembangan Aplikasi Android Sebagai Media Pembelajaran Kompetensi Pengoperasian Sistem Kendali Elektronik Pada Siswa Kelas XI SMK”. Skripsi. FT UNY 102
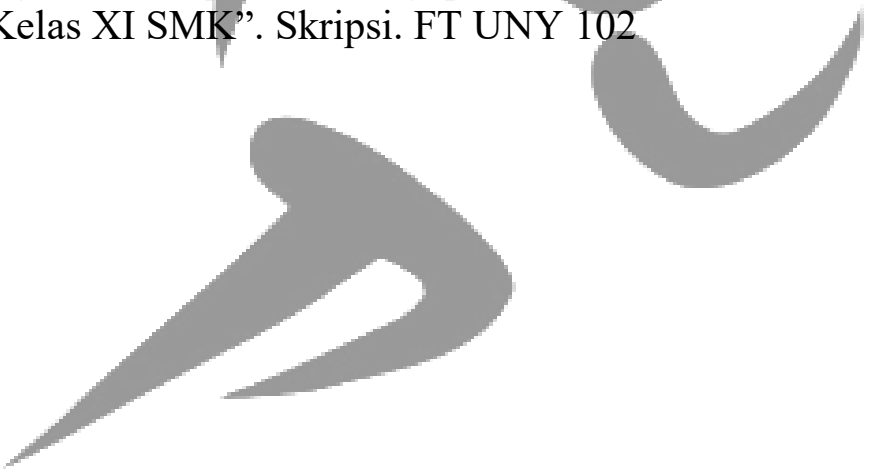

Journal Physical Education. Health and Recreation pubiseter 